\title{
Patterns of Nonarticular Rheumatism in a Rural Area of Bangladesh
}

\author{
M. MASUDUL HASSAN, ${ }^{1}$ SYED ATIQUL HAQ ${ }^{2}{ }^{\text {MINHAJ RAHIM CHOUDHURY, }}{ }^{3}$ MD. NAZRUL ISLAM, ${ }^{4} \mathrm{APARNA} \mathrm{DAS,}^{5}$ \\ GOBINDA BANIK, ${ }^{6}$ MOHAMMED TAWHIDUL ISLAM MONDAL, ${ }^{7}$ MD. RUSTOM ALI ${ }^{8}$
}

\begin{abstract}
s:
Objectives: Estimate the prevalence of nonarticular (soft tissue) rheumatism in a rural population of Bangladesh.

Methods: The survey was carried out in eight villages of Sonargaon upazila of Narayanganj district about 30 kilometers from Dhaka. All subjects of both genders (52 I 7) of $\geq 15$ years old of 8 villages were evaluated. Door to door survey was done to cover missing cases. Trained field workers identified subjects with musculoskeletal pain using Bengali version of the COPCORD (Community Oriented Program for the Control of Rheumatic Disease) questionnaire. Positive respondents were examined by trained internist and rheumatologists for definite non articular rheumatic disorders. COPCORD guideline was used for diagnosis.

Results: MSK pains (positive respondent) were I 260 (24.2\%) in out of 5217 (male 2556, female 266 I). Among of them definite soft tissue rheumatic diseases were identified in 439 (male 102 and female 337). Major occupations were house wives (54.7), weavers (I8\%), and peasants (5. I\%). Definite point prevalence of nonarticular rheumatism was $8.41 \%$ (male $3.7 \%$, female I I.09\%). The most common diseases were fibromyalgia (3.95\%), repetitive strain injury (2.3\%), nocturnal muscle cramp (0.59\%), myofascial neck pain $(0.48 \%)$, planter fasciitis $(0.46 \%)$.
\end{abstract}

Conclusion: Prevalence of nonarticular rheumatism is common in this rural community. Fibromyalgia is the leading disease.

Keyword: Nonarticular rheumatism, soft tissue rheumatism, fibromyalgia, repetitive strain injury.

\section{Introduction:}

Nonarticular rheumatism refers to a group of musculoskeletal (MSK) pain syndrome that results from pathology of extraarticular and extraosseous periarticular structures like soft tissue \& their synovial sheaths, entheses, muscles \& fascia. A major point conceptually is that pain from nonarticular rheumatism is not due to pathology of structures within the joint proper. Chronic widespread musculoskeletal pain has been subjected to several epidemiological studies during the last decade and approximately $10 \%$ of the general populations report such complaints. ${ }^{1}$ Chronic widespread musculoskeletal pain is the clinical hallmark of fibromyalgia

1. Medical Officer, Rhematology wing, Department of Medicine, BSMMU, Shahbag, Dhaka.

2. Professor of Rheumatlogy and Chairman, Dept. of Medicine, BSMMU, Shahbagh, Dhaka.

3. Prof. of Rheumatlogy, Dept. of Medicine, BSMMU, Shahbagh, Dhaka.

4. Prof. of Rheumatlogy, Dept. of Medicine, BSMMU, Shahbagh, Dhaka.

5. Assistant Prof. of Medicine, DMCH.

6. Lecturer, Pharmacology, SSMC and Mitford Hospital, Dhaka

7. Resident Surgeon, SSMC and Mitford Hospital, Dhaka.

8. Registrar, NIDC\&H, Dhaka.

Correspondence : Dr. M. Masudul Hassan, Medical Officer, Rheumatology wing, Department of Medicine, BSMMU, Shahbag, Dhaka. and the prevalence of fibromyalgia is reportedly 3-5\%, again with a significant female predominance. ${ }^{1}$ Many of the MSK pain conditions are self-limiting and respond to conservative measures. ${ }^{2}$ Prevalence data for nonarticular rheumatism have been reported in Europe and United States, but in Asia it is still emerging. ${ }^{3}$ The prevalence data of nonarticular rheumatism from the first Indian COPCORD survey (Stage 1) in 1996 was $5.5 \%$, in a Filipino urban study was 3.8\% \& 4\% in a Pakistani study. ${ }^{4-6}$ In the study conducted by Haq et al in a Bangladeshi rural area has shown fibromyalgia and other soft tissue rheumatic diseases were also common rheumatic disorders and their prevalence estimates $4.4 \%$ and $2.7 \%$ respectively in 2005 in another study in 2008 the prevalence of fibromyalgia was $2.9 \%{ }^{7,8}$ In a review where data reported from 15 countries of Asia/Europe in the Asia-Pacific region ofCOPCORD reflects the prevalence of musculoskeletal pain which varies from $11.6 \%$ to $45.4 \%$ and nonarticular rheumatism was one of the commonest rheumatic disorders in this region. ${ }^{9}$ The aim of this study is to gather data on nonarticular rheumatism in Bangladeshi rural community.

\section{Materials and methods:}

Out of 5217 participants 2485 men and 2732 women (from eight villages of Sonargaon) were interviewed in a house to house survey designed to determine musculoskeletal pain with the Bengali version of phase 2 questionnaire of COPCORD questionnaire. The positive respondents were screened by rheumatologists and Internists, experienced in 
rheumatology who tried to reach specific diagnosis. All of the respondents were 15 years and above.

Study was performed from November 2003 to April 2004. Sampling was done by non-probability method. In preparatory phase, interviewers were trained by rheumatology experts. COPCORD questionnaire was translated in Bengali in an easily understandable way. Modified data sheet was prepared by the author, which comprised information covering clinical features of all possible soft tissue rheumatic disorders as well as fibromyalgia tender points.

In the next phase, Union Parishad member, school teachers and Imams of Mosques were informed and consent was taken. They were briefed about the study before taking an interview and consent was taken. The appointed interviewers moved door to door and administered the questionnaire and interviewed the target people.

Phase 2 and phase 3 COPCORD questionnaires records the occurrence of musculoskeletal pain in various body sites by interviewers. It was the preparatory phase. Interviewers were university graduate and had previous experience with data collection in a rural area in health related epidemiological studies. Standard English COPCORD questionnaire was translated to Bengali, a language universally understood in Bangladesh. The subjects with possible definite disease were then examined by a doctor familiar with rheumatic diseases.

In the third phase doctors experienced with rheumatologic disorders examined the positive respondents complaints (occurrence of pain at muscles, bone and joints or any part of the body), screened by trained interviewers. Different cases were reexamined by rheumatologists. The diseases were diagnosed by available and accepted clinical criteria for example ACR criteria for $\mathrm{FM}^{17}$ and in their absence, by clinical judgments.

Data analysis was done by SPSS version 13. The prevalence was estimated by $95 \%$ confidence interval. The chi-square test was used for the difference between proportions.

\section{Results:}

There were 439 positive respondents identified in this study. The mean (+SD) age of positive respondents was 39.10+13 years. Most of the respondents were female (76.7\%).

There were 337 female and 102 male. Female were affected 3 times more frequently then male. $84 \%$ affected persons were married, $54.7 \%$ were housewives, $4.8 \%$ were laborers, $18 \%$ were weavers, $2.8 \%$ were mill workers, $5.1 \%$ were peasants, $2.5 \%$ were tailors, $2.3 \%$ were businessman, $2 \%$ were garment workers (Table-I).

Table-I

Socio-demographic character of total cases:

\begin{tabular}{|c|c|c|c|}
\hline Parameter & & $\begin{array}{c}\text { Number of } \\
\text { subjects }\end{array}$ & Percent $(\%)$ \\
\hline \multirow[t]{4}{*}{ Age (years) } & Mean+SD & $39.10+13$ & \\
\hline & & Range 16-80 & \\
\hline & Male & 102 & $23.3 \%$ \\
\hline & Female & 337 & $76.7 \%$ \\
\hline \multirow[t]{9}{*}{ Occupation } & Housewife & 240 & 54.7 \\
\hline & Labor & 21 & 4.8 \\
\hline & Weaver & 78 & 18 \\
\hline & Mill worker & 12 & 2.8 \\
\hline & Peasant & 22 & 5.1 \\
\hline & Tailor & 11 & 2.5 \\
\hline & Business & 10 & 2.3 \\
\hline & Garments worker & 9 & 2 \\
\hline & Others & 36 & 7.8 \\
\hline \multirow[t]{4}{*}{ Marital status } & Married & 368 & 83.8 \\
\hline & Unmarried & 26 & 5.8 \\
\hline & Widow/Widower & 42 & 9.6 \\
\hline & Separated & 3 & 0.8 \\
\hline \multirow[t]{4}{*}{ Education } & Illiterate & 271 & 61.8 \\
\hline & Primary & 104 & 23.8 \\
\hline & Secondary & 56 & 12.7 \\
\hline & Degree & 8 & 1.8 \\
\hline
\end{tabular}

Fibromyalgia was the most commonest disorder affecting soft tissue $(3.95 \%)$, followed by other periarticular diseases(2.3\%). In, diseases identified were rotator cuff disease $0.5 \%$, lateral epicondylitis $0.2 \%$, Achilles tendinitis $0.2 \%$, deQuervans tenosynvitis $0.1 \%$, bicipital tendonitis $0.1 \%$, infrapatellar bursitis $0.04 \%$, prepatellar bursitis $0.02 \%$, and occupational overuse syndrome $0.9 \%$, and other tendinopathy $0.3 \%$ (table-II). 


\section{Table-II}

Prevalence of soft tissue rheumatic disorders:

\begin{tabular}{lcc}
\hline Parameter & No of subjects & Percent (\%) \\
\hline Fibromyalgia & 206 & 3.95 \\
Periarticular diseases(Rotator cuff disease, lateral epicondylitis, & 120 & 2.30 \\
Achilles tendinitis, deQuervans tenosynovitis, bicipital & & \\
tenosynovitis, infrapatellar bursitis, prepatellar bursitis, & & \\
occupational overuse syndrome and other tendinopathy) & 31 & 0.59 \\
Nocturnal muscle cramp & 25 & 0.48 \\
Myofascial neck pain & 24 & 0.46 \\
Planter fasciitis & 8 & 0.15 \\
Adhesive capsulitis & 6 & 0.12 \\
Myofascial pain syndrome & 3 & 0.06 \\
Anserine bursitis & 3 & 0.06 \\
Costochondritis & 2 & 0.04 \\
Anterior tibial compartment syndrome & 2 & 0.04 \\
Osgood Schlatters disease & 3 & 0.06 \\
Carpal tunnel syndrome & 1 & 0.02 \\
Teitzes syndrome & 1 & 0.02 \\
Lower rib pain syndrome & 1 & 0.02 \\
Reflex sympathetic Syndrome & 1 & 0.02 \\
Posterior chest wall Syndrome & 2 & 0.04 \\
Meralgia paresthetiica & 439 & 8.43 \\
\hline Total & & \\
\hline
\end{tabular}

The mean age of fibromyalgia patients were 39.4 and 38.6 in repetitive strain injury. Fibromyalgia patients were mostly female $(94.3 \%)$, repetitive strain injury was also more common among women. Both fibromyalgia ( $84.9 \%)$ and repetitive strain injury $(85.6 \%)$ were common in married people.

Table-III

Socio demographic relations between fibromyalgia and (RSI)

\begin{tabular}{lccc}
\hline & Fibromyalgia & Repetitive strain injury & Chi square test \\
\hline Total & 193 & 104 & \\
Age: mean +SD & $39.4+12.9$ & $38.6+13.9$ & \\
& $\mathrm{~T}=42.4, \mathrm{P}=0.000$ & $\mathrm{~T}=28.4, \mathrm{p}=0.000$ & \\
95\% CI (Range 16-80) & $37.6-41.3$ & $35.9-41.3$ & \\
Sex: Male & $11(5.7 \%)$ & $43(41.3 \%)$ & $\mathrm{X}^{2}=57.73, \mathrm{P}<0.00$ \\
$\quad$ Female & $182(94.3 \%)$ & $61(58.7 \%)$ & \\
Married & $141(84.9 \%)$ & $77(85.6 \%)$ & $\mathrm{X}^{2}=4.93, \mathrm{P}<0.00$ \\
\hline
\end{tabular}




\section{Discussion:}

Prevalence of nonarticular rheumatism in Bangladesh (except fibromyalgia 2.7\%) was a little higher than that in some Asian countries, $2.5 \%$ to $5.7 \%$ in China and 3.8\% in Philippine. $8,9,14$ Those studies were conducted to see overall prevalence of rheumatic disorders in contrary to our study which focused to soft tissue rheumatic disorders only. Prevalence of nonarticular rheumatism in our series $(8.4 \%)$ was higher than that of the previous study $(7.1 \%) .{ }^{7}$ In the present study, male female ratio was 1:3 which is also consistent with previous study. It was also observed that married and housewives are the main sufferers of soft tissue disorders.

In our series, the most common rheumatic disorder was fibromyalgia (point prevalence $4 \%$ ), it was $4.4 \%$ in the previous study. ${ }^{7,8}$ Fibromyalgia alone is the major contributor in our study followed by repetitive strain injury $(2.3 \%)$ and $94.1 \%$ subjects were found to be female. In a North American study, the prevalence of fibromyalgia was $2.0 \%$ for both sexes, ${ }^{18}$ in Denmark $0.66 \%,{ }^{21}$ in Finland $0.75 \% .{ }^{22}$ Fibromyalgia was seldom seen in China; only two cases were found in Shantou among 2,350 people and one in Taiwan in 3,915 people. ${ }^{10}$ Twenty eight years ago, the prevalence of FM was reported ranging from $0.5 \%$ to $5 \%$ and up to $15.7 \%$ in the clinic in a western population. ${ }^{19}$ Fibromyalgia affected women more than men in all studies including our one. Bangladeshi and other people of Asia except China, has increased prevalence of soft tissue disorders than Europeans.

Prevalence rates of rheumatic pain reported from Australia, Bangladesh, India, Indonesia, Philippines, Thailand and Vietnam were $33 \%, 26.3 \%, 18.2 \%, 23.6 \%$ to $31.3 \%, 16.3 \%$, $36.2 \%$ and $14.9 \%$, respectively, ${ }^{8-15}$ indicating variation by locality, methods of survey, definition of disease categories and ethnic group. It is thus of importance to investigate how socioeconomic status, environmental differences, sex, age, occupation, and awareness of seeking medical care influence the prevalence of rheumatic complaints. Regarding nonarticular rheumatism, studies are not as enriched as other rheumatic disorders and it will be more informative if we can study individual soft tissue disease in our society.

Widespread pain was more common in three South Asian ethnic groups ranging from 2.7 to 5.8 in the different South Asian subgroups ${ }^{23}$. The prevalence in this study was higher.

Rotator cuff disease, lateral epicondylitis, Achilles tendinitis, nocturnal muscle cramp, myofascial neck pain, planter fasciitis are present in a alarming ratio. In our study, repetitive strain injury is present in both male and female and the ratio is $2: 3$. Both the conditions were documented more in the married group, which is nearly $90 \%$.

\section{Conclusion:}

The high prevalence of soft tissue diseases exerts substantial burden in our community. Its prevalence is very high and females are the main sufferer. Soft tissue rheumatic disorders are more prevalent among married population. Fibromyalgia is a disease of female, whereas repetitive strain injury is present in both male and female. Lifetime recurrence and disease burden and their research for the elements of burden, disability and economic impact need to be addressed. Prevalence of repetitive strain injury is another important field to be studied. Another important subject is how urban and rural influences affect diseases.

\section{Conflict of Interest : None}

\section{References:}

1. Gran JT. The epidemiology of chronic generalized musculoskeletal pain. Best Pract Res Clin Rheumatol. 2003;17(4):547-56

2. Robert P Sheon, Zacharia Isaac, Paul L Romain; Overview of soft tissue rheumatic disorders; UpToDate

3. J Dharmawan, HA Valkanberg, KD Muirden; The prevalence of soft tissue rheumatism, Rheumatology int, 1995, 15, 121-124.

4. Chopra A, Patil J, Billempelly V, Relwani J, Tandle HS.Prevalence of rheumatic diseases in a rural population in western India: a WHO-ILAR COPCORD Study. J Assoc Physicians India. 2001; 49: 240-6

5. Dans LF, Tankeh-Torres S, Amante CM, Penserga EG. The prevalence of rheumatic diseases in a Filipino urban population: a WHO-ILAR COPCORD Study. J Rheumatol 1997; 24: 1814-1819

6. Farooqi A, Gibson T. Prevalence of major rheumatic diseases in the adult population of north Pakistan. Br J Rheumatol 1998; 37: 491-5

7. Haq SA, Darmawan J, Islam MN, Uddin MZ, Das BB, Rahman F, Chowdhury MA, Alam MN, Mahmud TA, Chowdhury MR, Tahir M. Prevalence of rheumatic diseases and associated outcomes in rural and urban communities in Bangladesh: a COPCORD study. J Rheumatol. 2005 Feb;32(2):348-53

8. Haq, S.A., Darmawan, J., Islam, N., Ahmed, M., Banik, S.K., Rahman, A.K.M.F., Alam, M.N., Tahir, M., \& Raskir, J.J. (2008). Incidence of musculoskeletal pain and Rheumatic disorders in a Bangladeshi rural community: A WHOAPLAR-COPCORD study. International Journal of Rheumatic Diseases, 11, 216-223

9. Haq SA, Rasker JJ, Dharmawan J, Chopra A. WHO-ILAR COPCORD in the Asia Pacific-the past, present and future. Intern J Rheum Dis 2008; 2: 4-10 
10. Qing Yu Zeng, Ren Chen, John Darmawan, Zheng Yu Xiao, Su Biao Chen, Richard Wigley, Shun Le Chen, and Nai Zheng Zhang, Rheumatic Diseases in China, Arthritis Res Ther. 2008; 10(1): R17. Published online 2008 January 31. doi: $10.1186 /$ ar2368

11. Minaur N, Sawyers S, Parker J, Darmawan J. Rheumatic disease in an Australian Aboriginal community in North Queensland, Australia. A WHO-ILAR COPCORD survey. J Rheumatol. 2004; 31:965-972

12. Chopra A, Saluja M, Patil J, Tandale HS. Pain and disability, perceptions and beliefs of a rural Indian population: a WHOILAR COPCORD study. J Rheumatol. 2002; 29:614-621.

13. Darmawan J, Valkenburg HA, Muirden KD, Wigley RD. Epidemiology of rheumatic diseases in rural and urban populations in Indonesia. Ann Rheum Dis. 1992; 51: 525528.

14. Dans LF, Tankeh-Torres S, Amante CM, Penserga EG. The prevalence of rheumatic diseases in a Filipino urban population: a WHO-ILAR COPCORD study. J Rheumatol. 1997; Sep 24(9):1814-1819.

15. Chaiamnuay P, Darmawan J, Muirden KD, Assawatanabodee P. Epidemiology of Rheumatic disease in rural Thailand: a WHO-ILAR COPCORD study. J Rheumatol. 1998; 25: 1382-1387.

16. Minh Hoa TT, Darmawan J, Chen SL, Van Hung N, Thi Nhi $\mathrm{C}$, Ngoc An T. Prevalence of the rheumatic diseases in urban Vietnam: a WHO-ILAR COPCORD study. J Rheumatol. 2003; 30: 2252-2256.
17. Wolfe F, Smythe HA, Yunus MB, Bennett RM, Bombardier C, Goldenberg DL, Tugwell P, Campbell SM, Abeles M, Clark P, Fam AG, Farber SJ, Fiechtner JJ, Franklin CM, Gatter RA, Hamaty D, Lessard J, Lichtbroun AS, Masi AT, McCain GA, Reynolds WJ, Romano TJ, Russell IJ, Sheon RP: The American College of Rheumatology 1990 criteria for the classification of fibromyalgia: report of the Multicenter Criteria Committee. Arthritis Rheum 33:160172,1990

18. Frederick Wolfe, Kathryn Ross, Janice Anderson, I. Jon Russell, and lies1 hebert, The prevalence and characteristics of fibromyalgia in the general population, arthritis \& rheumatism, volume 38 number 1, January 1995, pp 19-28

19. Neumann L, Buskila D. Epidemiology of fibromyalgia. Curr Pain Headache Rep. 2003 Oct; 7(5):362-8.

20. Wolfe F, Cathey MA. Prevalence of primary and secondary fibrositis. J Rheumatol. 1983 Dec; 10(6):965-8.

21. Prescott E, Kjoller M, Jacobsen S, Bülow PM, DanneskioldSamsoe B, Kamper-Jorgens. Fibromyalgia in the adult Danish population: I. A prevalence study. Scand J Rheumatol. 1993; 22(5):233-7.

22. Makela M, Heliovaara M. Prevalence of primary fibromyalgia in the Finnish population. BMJ. 1991 Jul 27; 303(6796):216-9.

23. Palmer B, Macfarlane G, Afzal C, Esmail A, Silman A, Lunt M. Acculturation and the prevalence of pain amongst South Asian minority ethnic groups in the UK. Rheumatology (Oxford). 2007 Jun; 46(6):1009-14. Epub 2007 Mar 31. 